\title{
Induction of Seedlessness in Citrus: From Classical Techniques to Emerging Biotechnological Approaches
}

\author{
Aliza Vardi, Ilan Levin, and Nir Carmi ${ }^{1}$ \\ Institute of Plant Sciences, A.R.O. The Volcani Center, P.O. Box 6, Bet-Dagan 50250, Israel
}

\begin{abstract}
AdDitional INDEX wORDs. citrus, cytoplasmic male sterility, seedless, parthenocarpy, mutation breeding, ploidy
Abstract. Seedlessness can be obtained through parthenocarpy (i.e., fruit formation without fertilization or embryo abortion). In practice, the actual reduction in seed number in parthenocarpic plants is often exaggerated by coupling parthenocarpy with self-incompatibility or male sterility. Traits related to seedlessness, such as parthenocarpy, can be introduced into genetic accessions through conventional cross-breeding. However, conventional breeding in Citrus L. species faces several limitations. First, these species have long juvenile (nonflowering) periods during which a relatively thick canopy develops, which limits the size of seedling populations that can be maintained for further evaluation. Second, they have a narrow genetic base, which limits the availability of alternative alleles that could be introgressed into other lines for the formation of a particular phenotype such as parthenocarpy. Third, breeding efforts are limited by the lack of knowledge of the mode of inheritance of specific characteristics. Fourth, and last, breeding efforts are limited by the polygenic nature of many important traits. Despite these limitations, conventional breeding in fruit trees has yielded improved cultivars and will most likely continue to be a very important strategy. However, emerging biotechnological approaches should be continuously evaluated for their potential for expediting such breeding efforts. The objective of this review is to present, evaluate, and discuss conventional and emerging biotechnological approaches for the induction and maintenance of seedlessness in a variety of crops. Particular attention will be paid to citrus crops, including the presentation and discussion of some preliminary data on the genetic inheritance of parthenocarpy.
\end{abstract}

Citrus is a common term for a genus (Citrus) of flowering plants in the family Rutaceae, documented as early as the Chinese Book of History, dated 1000 BCE. Citrus fruit are valued for their vivid colors; strong fragrances; sharp, delicious tastes; and high nutritional value. Today, citrus ranks first in world fruit production [Food and Agriculture Organization of the United Nations (FAO), 2005].

It seems likely that the center of origin of commercially important citrus species lies in southeast Asia; many of these species probably originated in China. From the proposed dispersal history of ancestral taxa, it seems that although orange [Citrus sinensis (L.) Osbeck.], lemon [Citrus limon (L.) Burm. f.], mandarin (Citrus reticulata Blanco), pummelo (Citrus grandis Osbeck), and grapefruit (Citrus paradisi Macf.) are now distributed worldwide, they share a relatively narrow genetic base. All were initially selected by humans and later propagated through apomictic embryos, cuttings, or grafting. Nearly all the variation in the polyembryonic cultivars appears to be the result of apomixis and somatic mutations. For centuries, some zygotic seedlings have been selected and propagated, such as the 'Clementine' mandarin and grapefruit.

Seeded grape (Vitis vinifera L.), citrus, and watermelon (Citrullus lanatus Thunb.) were long accepted by consumers. However, during the past few decades, consumer interest in seedless fruit has increased, and seedlessness has become an important characteristic for fresh market fruit, including citrus. Received for publication 14 Mar. 2007. Accepted for publication 18 Sept. 2007.
${ }^{1}$ Corresponding author. E-mail: nircarmi@volcani.agri.gov.

\section{Parthenocarpy}

Parthenocarpy, literally meaning virgin fruit, is the natural, artificially induced, or genetically modified production of fruit without fertilization. In the absence of pollination, parthenocarpic plants will set seedless fruit (Gustafson, 1942). Thus, parthenocarpy can be regarded as a primary requirement for the production of seedless fruit.

Various types of parthenocarpy have been recognized. A distinction is often made between obligatory parthenocarpy, which always results in seedless fruit, and facultative parthenocarpy, which results in seedless fruit only when pollination is prevented. A distinction is also often made between vegetative parthenocarpy, which allows fruit set without pollination, and stimulated parthenocarpy, in which fruit set follows pollination, but subsequent fertilization is prevented, resulting in the production of seedless fruit. Seedlessness can also be obtained through stenospermocarpy, in which pollination and fertilization occur and embryo abortion is the cause of seedlessness.

Fruit development and seed set in flowering plants normally occur in a coordinated manner, after pollination of the stigma and a subsequent double fertilization event in the ovule of the flower (Gillaspy et al., 1993). When the egg and central cell of the female gametophyte do not fuse with sperm cells, they remain in a quiescent state and eventually degrade as the flower undergoes senescence (O'Neill and Nadeau, 1997). This observation has led to the theory that signaling processes are required for the development of the fertilization products necessary for the initiation of seed and fruit development (Raghavan, 2003). Various phytohormones, including gibberellins (GAs), cytokinins, and auxins, are involved in the signaling processes that 
follow pollination and fertilization, and are prerequisites for the further growth and development of seeds and fruit (Coombe, 1960; Fos et al., 2000, 2001; Garcia-Martinez and Hedden, 1997; Nitsch, 1952, 1970). Developing seeds appear to be important for fruit growth and development because they are a source of the phytohormones that are required continuously throughout seed and fruit formation (Archbold and Dennis, 1985; Ben-Cheikh et al., 1997; Eeuwens and Schwabe, 1975; Garcia-Martinez et al., 1991; Nitsch, 1970; Ozga et al., 2002; Swain et al., 1997; Talon et al., 1990).

When fruit development is separated from fertilization and seed development, the resulting parthenocarpic fruit are seedless (Fos et al., 2000; Talon et al., 1992; Varoquaux et al., 2000). Parthenocarpy has a genetic basis (de Menezes et al., 2005; Goetz et al., 2006; Lin et al., 1984; Pike and Peterson, 1969), and has been exploited by farmers and plant breeders for the production of seedless fruit (Sykes and Lewis, 1996). Elevated levels of endogenous phytohormones have been observed during parthenocarpic fruit set (George et al., 1984; Talon et al., 1990, 1992), suggesting that the increased supply of phytohormones to fruit from sources other than seeds may be sufficient to induce fruit growth. Accordingly, parthenocarpy can be induced in arabidopsis [Arabidopsis thaliana (L.) Heynh.] and a variety of agricultural species by the exogenous application of auxins, cytokinins, or GAs (Gillaspy et al., 1993; Vivian-Smith and Koltunow, 1999), or through the expression of auxin biosynthesis genes in ovaries and ovules (Carmi et al., 2003; Mezzetti et al., 2004; Rotino et al., 1997).

Goetz et al. (2006) recently demonstrated that fruit set is inhibited by the negative regulator initiation $A R F 8$, because loss-of-function arf 8 alleles allow parthenocarpy. Goetz et al. (2006) proposed that the auxin signal induced by pollination leads to the phosphorylation and subsequent proteolytic degradation of the Aux/indole-3-acetic acid (IAA) protein, which triggers the subsequent expression of fruit initiation genes. However, in the arf 8 mutant, the inhibitory complex cannot be formed and parthenocarpic fruit develop. Nonetheless, the molecular events directly involved in the initiation of fruit development and their link to plant hormone signal transduction processes remain unknown (Goetz et al., 2006).

Parthenocarpy is an economically valuable trait in a number of horticultural crops. Consumers often prefer seedless fruit for aesthetic reasons, because many such fruit have a more attractive appearance and offer added convenience, in terms of preparation and consumption. Manufacturers prefer them because they facilitate processing. For example, the processing of parthenocarpic tomato (Solanum lycopersicum L.) is easier because no seeds have to be removed. Additionally, these seedless cultivars have simplified growth requirements, particularly when grown in greenhouses or under unfavorable climatic conditions (Yin et al., 2006).

As mentioned earlier, growth regulators, such as synthetic auxins, can be used to induce parthenocarpic fruit set. However, these agricultural practices increase production costs, and applications of auxins or other growth regulators may cause other fruit defects. The drawbacks associated with these chemical treatments can be overcome through exploitation of genetic parthenocarpy, a trait that is currently being widely introgressed into several crops, including banana [Musa acuminata Colla (AA) $\times$ Musa balbisiana Colla $(\mathrm{BB})]$, grape, watermelon, and cucumber (Cucumis sativus L.) (Varoquaux et al., 2000). Genetic parthenocarpy can also be artificially established with exogenous genes, controlled by ovary- or ovule-specific promoters that drive the oversensitization to, or the accumulation of, auxins in carpel tissues before anthesis (Carmi et al., 1997, 2003; Ficcadenti et al., 1999).

\section{Factors Influencing Seedlessness}

Parthenocarpic tomato mutants, as well as parthenocarpic bananas, pineapples [Ananus comosus (L.) Merr.], and some grape and citrus cultivars, are good examples of facultative parthenocarpy because they produce seedless fruit in the absence of fertilization. Therefore, in many of these cases, seedlessness can be obtained by combining parthenocarpy with factors that inhibit fertilization. Factors inducing seedlessness include certain environmental conditions, such as low or high temperatures, chemical treatments, chromosomal aberrations, and genetic factors, such as genes controlling meiosis (Lin et al., 1984; Nuez et al., 1986; Pike and Peterson, 1969; Vardy et al., 1989a,b). Alternatively, self-incompatibility can be combined with the trait of parthenocarpy.

In grape, two kinds of seedlessness exist (Ledbetter and Ramming, 1989). The first is caused by parthenocarpy, but the berries of these grape cultivars (e.g., Corinth) are very small. The second kind of seedlessness in grape is caused by stenospermocarpy, which refers to fruit with seeds that are only partially formed as a result of embryo abortion. Traces of the seeds are present, but they are very soft. To obtain welldeveloped berries, it is necessary to apply GAs. In grape, $\mathrm{GA}_{3}$ has been shown to induce cellular expansion in mesocarp tissue and thus increase berry size and reduce the seed traces. The optimum concentration and timing of GA application is cultivar dependent.

In crops such as tomato, pea (Pisum sativum L.), and cucumber, there is evidence that parthenocarpic fruit set is associated with high levels of endogenous auxin and GAs in the ovary (Bukovac and Nakagawa, 1967; Fos et al., 2000, 2001; Rebers et al., 1999; Robinson et al., 1971; Rodrigo and GarcíaMartinez, 1998). Applications of GAs, auxins, and cytokinins have been shown to induce parthenocarpy, with various plant species responding differently to auxins and GAs (Gustafson, 1936; Mapelli et al., 1978; Nitsch, 1970; Schwabe and Mills, 1981; Vivian-Smith and Koltunow, 1999). High levels of endogenous auxin and GAs occur in naturally parthenocarpic tomato and citrus cultivars (George et al., 1984; Talon et al., 1990, 1992). In arabidopsis, $\mathrm{GA}_{3}$ primarily influences mesocarp cell division, whereas mesocarp and exocarp cell enlargement occur after auxin treatment. In grape, $\mathrm{GA}_{3}$ has been observed to induce cellular expansion in mesocarp tissues (Srinivasan and Morgan, 1996). In tomato, $\mathrm{GA}_{3}$ treatments have also been shown to induce mesocarp cell expansion with restricted cellular division, whereas auxin treatments stimulate cell division (Bünger-Kibler and Bangerth, 1982).

\section{Seedlessness in Parthenocarpic Citrus Cultivars}

A citrus cultivar is considered to be seedless if it is able to produce normal fruit that contains no seeds, aborted seeds, or a significantly reduced number of seeds. Parthenocarpy is the primary requirement for the production of seedless fruit because, in parthenocarpic plants, the unfertilized ovary can develop into a normal fruit. Therefore, parthenocarpy, coupled with a lack of cross- or self-pollination, can yield seedless fruit. 
Self-incompatible, parthenocarpic cultivars can set seedless fruit when grown in blocks isolated from cross-pollinators. In addition, the combination of parthenocarpic capability with complete male sterility should always result in seedless fruit.

The majority of commercial citrus cultivars exhibit some level of parthenocarpy in the absence of pollination, resulting in the production of seedless fruit. For this reason, the cultivation of citrus in isolated blocks often results in seedlessness (Chao et al., 2005). Different self-incompatible mandarin cultivars grown in adjacent fields can set seeded fruit, if the distance between the fields is small enough to allow pollinators to fly from one field to the other. Growers in the Valencia region of Spain have experimented with a field separation method involving isolated blocks. 'Clemenules', a sweet, self-incompatible mandarin cultivar, were grown in two 121.4-ha fields $9.7 \mathrm{~km}$ away from the nearest 'Clementine' mandarin farm. This separation was sufficient to allow for the production of "absolutely" seedless 'Clemenules' fruit. However, the isolated-block approach may not be always practical because of limited land resources, particularly in densely populated regions or countries. Furthermore, the use of distant, isolated blocks is not compatible with current, highly intensive agricultural practices. Therefore, the development of new cultivars with higher levels of seedlessness is still necessary.

Breeding efforts for high-quality seedless citrus fruit have increased during the past few decades. However, these efforts have produced only a few cultivars $\{$ e.g., Satsuma mandarin (Citrus unshiu Marc.), Washington Navel orange (C. sinensis), Tahiti lime [Citrus latifolia (Yu. Tanaka) Tanaka], and Oroblanco $(C$. grandis $\times C$. paradisi $)\}$ that can be considered "absolutely" seedless. In 'Satsuma' and 'Washington Navel', female and male sterility have been found, in addition to parthenocarpy (Iwamasa, 1966), increasing the likelihood of the production of completely seedless fruit. In fact, in some citrus cultivars, the degree of male sterility can be an indication of the ability of the cultivar to set seedless or very few seeded fruit. In 'Satsuma', univalents are occasionally created during meiosis (Iwamasa, 1966), and some 'Satsuma' cultivars exhibit cytoplasmic male sterility (CMS) (Yamamoto et al., 1997). In 'Navel' orange, there is a genetically controlled degradation of pollen mother cells that occurs before the first meiotic division (Iwamasa, 1966). In 'Tahiti' lime and 'Orblanco', parthenocarpy is accompanied by chromosomal irregularity during meiosis, reflecting the triploid origins of these lines (Soost and Cameron, 1980). Genetic and cytological analyses of inbred, parthenocarpic progeny of 'Wilking' mandarin (Vardi and Spiegel-Roy, 1981) revealed that a recessive gene is responsible for asynapsis in meiosis, resulting in pollen, as well as ovule, abortion and subsequent parthenocarpy. Irradiation of budwood, leading to chromosome aberrations such as inversions or translocations, results in high frequencies of pollen and ovule abortion.

According to Monselise (1986), auxin levels peak sharply $10 \mathrm{~d}$ after anthesis, and exogenous GA is essential for fruit development and the prevention of fruit abscission. Although exogenous $\mathrm{GA}_{3}$ treatments have been shown to improve fruit set in numerous citrus cultivars (Garcia-Martinez and Garcia Papi, 1979), these treatments did not increase fruit set in the 'Satsuma' mandarin (Coggins and Hield, 1968). The accumulated evidence strongly supports the suggestion that GAs, rather than auxin, are particularly essential to citrus fruit development. Differences in the hormonal contents of the obligatory parthe- nocarpy of the 'Satsuma' mandarin and traits such as selfincompatible, stimulative parthenocarpic 'Clementine' mandarin have been characterized (Talon et al., 1990, 1992). These analyses revealed differences in GA levels, as measured by gas chromatography and mass spectrometry during the early phases of fruit growth, from $24 \mathrm{~d}$ before anthesis to $40 \mathrm{~d}$ after anthesis. Gibberellin concentrations during anthesis were significantly higher in the ovaries of 'Satsuma' than in the ovaries of 'Clementine' mandarin. Similar levels of free IAA levels were observed in the two cultivars, whereas during the same time period, the concentrations of bound IAA increased dramatically in 'Clementine' mandarin and only slightly in 'Satsuma.' Abscisic acid (ABA) reached its peak level at the petal-fall stage. 'Clementine' mandarin was found to contain higher levels of free ABA than 'Satsuma,' whereas bound ABA levels were higher in 'Satsuma'. In contrast to the situation in tomato discussed earlier, applications of exogenous auxin did not promote fruit set in either 'Satsuma' or 'Clementine' mandarin. It therefore seems unlikely that the concentration of free IAA is a limiting factor in the triggering of citrus fruit set. Gibberellin applications suppressed the natural increase in free ABA during the development of 'Clementine' mandarin fruit. The relative balance between growth-promoting GAs and the growth inhibitor effect of $\mathrm{ABA}$ appears to play an important role in the regulation of fruit development in seedless mandarin. It has been suggested that GA levels during anthesis are the initial trigger responsible for appropriate fruit development. Increases in endogenous GA levels have also been observed in the parthenocarpic 'Fino Clementine' (Garcia-Papi and Garcia-Martinez, 1984), parthenocarpic pear (Pyrus communis L.) (Gil et al., 1972), and parthenocarpic grape cultivars (Coombe, 1960).

Several studies have suggested that pollination leads to increases in GA content in pear and tomato (Pharis and King, 1985; Sjut and Bangerth, 1981). Ben-Cheikh et al. (1997) demonstrated that pollination increases the levels of GAs in developing citrus ovaries and that this effect is not a result of the pollen itself. The concentration of endogenous GA in 'Satsuma' (obligatory parthenocarpic) reaches its highest level at anthesis, in contrast to the situation in self-incompatible cultivars (stimulative parthenocarpy) in which endogenous GA levels are not enhanced at anthesis (Garcia-Papi and GarciaMartinez, 1984; Talon et al., 1992).

\section{Genetic Background of Parthenocarpy}

Parthenocarpy in tomato has been well studied. Three independent mutations, pat (Soressi and Salamini, 1975), pat-2 (Philouze and Maisonneuve, 1978), and pat-3/pat-4 (Lukyanenko, 1991), induce facultative parthenocarpic fruit development in this crop. These mutations are associated with high levels of active GA in the 13-hydroxylation pathway (Fos et al., 2000, 2001). pat-2, a recessive mutation that induces facultative parthenocarpic fruit development in tomato, is associated with elevated concentrations of $\mathrm{GA}_{1}$ and $\mathrm{GA}_{3}$ in the ovaries before pollination. This mutation is also associated with aberrations in ovule development, which reduce the production of viable female gametes (Mazzucato et al., 1998). Another indication of a genetic link between parthenocarpy and GA metabolism is found in the spindly (spy) mutants of arabidopsis. Relative to the wild type, spy mutants have longer hypocotyls, leaves that are a lighter shade of green, increased stem elongation, early flowering, parthenocarpy, and partial 
male sterility. Three independent recessive mutations at the SPINDLY (SPY) locus of arabidopsis confer resistance to the GA biosynthesis inhibitor paclobutrazol (Jacobsen and Olszewski, 1993).

Parthenocarpy was proposed as a mechanism for overcoming fruit set inhibition in the gynoecious cucumber (Denna, 1973). Although this trait has been shown to be under genetic control, no consensus has been reached regarding the number of genes or mode of gene action involved. Hypotheses have ranged from a single recessive gene through several incomplete recessive genes to one dominant gene with three additional additive genes (Ponti and Garretsen, 1976; Sun et al., 2004). Despite this lack of knowledge and the difficulties associated with the genetic introduction of parthenocarpy, attributed to the influence of the genetic background, commercial greenhouse cucumber cultivars carrying the parthenocarpy trait have been successfully developed.

We recently conducted an experiment aimed at shortening the nonflowering period of citrus crops and allowing for the rapid assessment of parthenocarpic ability. During this experiment, young hybrid seedlings that had the "absolutely" parthenocarpic 'Satsuma' mandarin as a female parent and different pollen donors were grafted and grown in a screen house (as described in Vardi et al., 2000). Data on the ages of flowering plants, pollen fertility, fruit set, and the number of seeds per fruit were collected and analyzed over a period of 4 years. Hybrids that set only seeded fruit were considered nonparthenocarpic, whereas hybrids that set only seedless fruit, or a mixture of seeded and unseeded fruit, were considered parthenocarpic. As shown in Table 1, the parthenocarpic to nonparthenocarpic ratios ranged from $1: 1$ to $15: 1$, mostly in favor of the parthenocarpic progeny. Most of these segregation ratios support the hypothesis that parthenocarpy in 'Satsuma' is encoded by at least two dominant complementary genes, with 'Satsuma' being heterozygous for these genes. In comparison, it is quite interesting to note that parthenocarpy in diploid banana ( $M$. acuminata) seems to depend on three dominant complementary genes with segregation ratios ranging from 1:1 to $1: 7$, the latter favoring the nonparthenocarpic progeny. Thus, although similar segregation ratios were observed in the two crops, the relationships in diploid banana favor the production of nonparthenocarpic progeny (Simmonds, 1953). This difference may reflect the possibility that some of the pollen parents used in our study may harbor one or more of these dominant genes. Indeed, the pollen donors 'Clementine' mandarin, 'Edit',
'Ellendale', 'Fortune', 'Michal', and 'Nova', which were all included in our study, display parthenocarpy when grown in isolated blocks, whereas the parthenocarpic natures of 'Niva', 'Shani', 'Trovita', and 'Wilking' are unknown, because they all display self-compatibility.

\section{Ploidy and Cytoplasmic Male Sterility}

Another approach for eliciting seedlessness involves the coupling of parthenocarpy with male sterility. Sterility can result from increased ploidy or cytoplasmic manipulation. The potential of ploidy manipulation for the production of seedless citrus cultivars has long been recognized. Ploidy manipulation using crosses between diploids and tetraploids has yielded several valuable triploid cultivars, including 'Oroblanco' and 'Melogold' (C. grandis $\times C$. paradisi) (Soost and Cameron, 1980, 1985), and 'Winola' (Spiegel-Roy and Vardi, 1992).

Until a few decades ago, tetraploids appeared to occur almost entirely as apomictic seedlings. The only genetic difference between these tetraploids and their sister apomictic diploids is the doubled number of chromosomes in the tetraploids. For this reason, they can be considered autotetraploids. There are some morphological and physiological differences between the diploids and the tetraploids. Tetraploids are characterized by increased leaf thickness, differences in color and shape, slower growth rates, and longer juvenile periods. However, most of the morphological and physiological differences apply for autotetraploids.

Spontaneous autotetraploids occur in many polyembryonic citrus cultivars (Cameron and Frost, 1968). Tetraploid trees of monoembryonic citrus cultivars can be obtained through colchicine treatment (Oiyama and Okudai, 1986). Tetraploids can also be produced through protoplast fusion. During the past few decades, a great deal of progress has been made in citrus somatic hybridization. Somatic hybrid plants have been produced from more than 300 different intergeneric and interspecific parental combinations (Grosser et al., 2000; Grosser and Gmitter, 1990; Guo and Deng, 2001; Ohgawara et al., 1985). For citrus somatic hybridization, protoplast-derived, embryogenic, apomictic calli are usually fused with mesophyll-derived protoplasts, which usually do not divide (Grosser and Gmitter, 1990). This approach is being used successfully for the production of triploids (Grosser and Gmitter, 2005; Grosser et al., 2000). Spontaneous triploids occur naturally in citrus as a result of the fusion of a haploid gamete and an unreduced diploid

Table 1. Genetic segregation of parthenocarpy among Citrus hybrids obtained from different crosses with 'Satsuma' mandarin.

\begin{tabular}{|c|c|c|c|c|c|c|}
\hline \multicolumn{4}{|c|}{ Genetic segregation $P\left(\chi^{2}\right)$} & \multirow{2}{*}{$\begin{array}{c}\text { Seeded } \\
\text { offspring (n) }\end{array}$} & \multirow{2}{*}{$\begin{array}{c}\text { Seedless } \\
\text { offspring (n) }\end{array}$} & \multirow[b]{2}{*}{ Pollen parent } \\
\hline $15: 1$ & $7: 1$ & $3: 1$ & $1: 1$ & & & \\
\hline$* * *$ & $* * *$ & $* * *$ & NS & 24 & 27 & Clementine mandarin \\
\hline$* * *$ & NS & $*$ & $* * *$ & 23 & 118 & Edit \\
\hline$* * *$ & NS & NS & $* * *$ & 14 & 62 & Fortune \\
\hline$* * *$ & NS & NS & $* * *$ & 9 & 36 & Michal \\
\hline NS & NS & $* *$ & $* * *$ & 3 & 41 & Niva \\
\hline$* * *$ & $* *$ & NS & $*$ & 10 & 23 & Shani \\
\hline NS & NS & NS & $* *$ & 1 & 11 & Trovita \\
\hline NS & * & $* * *$ & $* * *$ & 0 & 43 & Wilking \\
\hline
\end{tabular}

${ }^{\mathrm{Ns}} P\left(\chi^{2}\right)>0.05 ; * 0.01 \leq P\left(\chi^{2}\right)<0.05 ; * * 0.001 \leq P\left(\chi^{2}\right)<0.01 ; * * * P\left(\chi^{2}\right)<0.001$. 
gamete (Luro et al., 2004). In triploids, the second meiotic division is omitted and so the functional megaspore leads to the production of diploid megagametophytes (Esen et al., 1979). Embryo rescue is used to recover spontaneous triploid and $2 \mathrm{n} \times$ $4 n$ hybrid varieties from aborted seeds (Navarro et al., 2004). The rescued offspring tend to exhibit decreased female fertility and complete male sterile (Luro et al., 2004). A diverse collection of autotetraploids derived from diploid plants with desirable traits could also serve as tetraploid pollen parents in breeding programs aimed at the production of high-quality seedless triploids. Triploids tend to have longer juvenile periods and are generally thornier than diploids, but the thorns often become smaller in the fruit-bearing trees. As already mentioned, seedless citrus fruit can be produced through the introduction of parthenocarpy into self-incompatible or male-sterile breeding lines.

An additional option involves harnessing the potential of CMS. The CMS caused by nuclear-cytoplasmic interaction is most likely related to mitochondrial DNA and is maternally inherited. To date, CMS in Citrus has been found only in 'Satsuma' mandarin and 'Encore' (Citrus nobilis Andrews $\times C$. deliciosa Ten.) (Yamamoto et al., 1992, 1997). Citrus cytoplasmic hybrids (cybrids) produced by symmetrical fusion between protoplasts derived from embryogenic callus and mesophyll tissues have the nuclear genome of the mesophyll parent and the mitochondrial genome of the callus parent (Grosser et al., 1996; Moriguchi et al., 1996; Saito et al., 1993; Yamamoto and Kobayashi, 1995). Using this approach, 'Satsuma' cytoplasm was transferred into seeded cultivars (Guo et al., 2004; Yamamoto et al., 2001). However, the verdict is still out on this approach as the cybrid trees have not yet set fruit.

\section{Mutation Breeding}

Spontaneous mutations have played an important role in the development of new cultivars. Many spontaneous mutants characterized by better fruit color, longer time periods to fruit maturity, and seedlessness have been found in fruit tree crops, particularly apple (Malus $\times$ domestica Borkh.) and citrus. Records maintained by the FAO/International Atomic Energy Agency show that about 2000 crop cultivars with one or more useful traits that are the result of induced mutations were released worldwide over a period of 35 years. However, the frequency of spontaneous mutation is very low, and the level of competition in the global marketplace requires an accelerated process for the development of new, seedless fruit cultivars and the introduction of the seedlessness trait into existing commercial cultivars.

Research has shown that irradiation of fruit trees, with fast neutrons, $x$ rays, or gamma rays, is an efficient way of inducing mutations. In contrast, the use of chemical mutagens has been found to be inefficient (Broertjes, 1977; Broertjes and Van Harten, 1985, 1988; Lapins, 1983; Van Harten and Broertjes, 1989). A list of desirable traits that have been produced in various commercial tree cultivars through induced mutations is presented in Table 2 (Brown, 1975; Campbell and Lacey, 1982; Campbell and Wilson, 1977; Coutinho, 1975; Dayton, 1959, 1969; Hansche, 1988; Hearn, 1984; Hensz, 1971; Lapins, 1971; Mau et al., 1982; McIntosh and Lapins, 1966; Sanada et al., 1988; Spiegel-Roy, 1990; Tobutt, 1984; Vardi and SpiegelRoy, 1988) Radiation has been found to induce many nonlethal chromosome aberrations. Gamma radiation induces mainly recessive deletion mutations (Brock, 1979). Most of these mutation events are therefore relatively useless in fruit trees with long juvenile periods, in comparison with field crops in which self-crossing and backcrossing are simpler processes. One of the main challenges in mutation breeding is chimera formation, because a mutation in one cell event of multicellular apices are treated, and thus different mutation can be induced at the same apices together with nonmutant cells (Broertjes and Van Harten, 1988).

Buds from old cultivars, as well as newly released highquality selections from our mutation breeding program, were irradiated with different doses of ${ }^{60} \mathrm{Co}$, with the aim of inducing complete seedlessness, or a low number of seeds, in four different citrus cultivars [Table 3 (Spiegel-Roy and Vardi, 1981)]. 'Troyer' citrange [C. sinensis $\times$ Poncirus trifoliate (L.) Raf.] rootstocks were budded with treated individual buds to form the $\mathrm{mV}_{1}$ (mutation vegetative 1) shoot generation. To avoid the formation of chimeras, buds of $\mathrm{mV}_{1}$ were grafted to form an $\mathrm{mV}_{2}$ (mutation vegetative 2) population (Fig. 1, Table 4). The timetable of the initial selection process is presented in Table 4. Seeds were counted during the second and third seasons. We evaluated the fertility of pollen collected from mature anthers of low-seeded and control trees. Pollen fertility was determined by the acetocarmine smear method. Pollen grains from mature anthers were stained with $2 \%$ acetocarmine. Five hundred pollen

Table 2. List of commercially important traits resulting from induced mutations in various crops.

\begin{tabular}{llll}
\hline Trait & \multicolumn{1}{c}{ Crop } & & \multicolumn{1}{c}{ Reference } \\
\hline Compact tree growth & Apple & Malus $\times$ domestica Borkh. & Tobutt, 1984 \\
& Peach & Prunus persica (L.) Batsch & Hansche, 1988 \\
Disease and pest resistance & Apple & M. $\times$ domestica & Campbell and Wilson, 1977; \\
& & & McIntosh and Lapins, 1966 \\
& Grape & Vitis vinifera L. & Coutinho, 1975 \\
& Pear & Pyrus L. & Sanada et al., 1988 \\
Self-incompatibility & Sweet cherry & Prunus avium (L.) L. & Lapins, 1971; Mau et al., 1982 \\
& Apple & M. $\times$ domestica & Campbell and Lacey, 1982 \\
Fruit color & Apple & M. $\times$ domestica & Dayton, 1959, 1969 \\
& Grapefruit & Citrus paradisi Macfad. & Hensz, 1971 \\
Low acidity & Apple & M. $\times$ domestica & Brown, 1975 \\
Seedlessness & Citrus & Citrus L. & Hearn, 1984, 1986; Hensz, 1971; \\
& & & Spiegel-Roy, 1990; Vardi and Spiegel-Roy, 1988; \\
& & & Vardi et al., 1995, 1996 \\
\hline
\end{tabular}


Table 3. The effect of gamma irradiation on seedlessness in the mandarin cultivars Murcott, Orah (Spiegel-Roy and Vardi, 1992), Yafit (Spiegel-Roy and Vardi, 1981), and Michal (local Israeli cultivar).

\begin{tabular}{|c|c|c|c|c|c|c|c|c|}
\hline \multirow{3}{*}{$\begin{array}{l}\text { Gamma irradiation } \\
(\mathrm{krad})\end{array}$} & \multicolumn{8}{|c|}{ Cultivar } \\
\hline & \multicolumn{2}{|c|}{ Murcott } & \multicolumn{2}{|c|}{ Orah } & \multicolumn{2}{|c|}{ Yafit } & \multicolumn{2}{|c|}{ Michal } \\
\hline & Trees (n) & Seedless (\%) & Trees (n) & Seedless $(\%)$ & Trees (n) & Seedless $(\%)$ & Trees (n) & Seedless $(\%)$ \\
\hline 2.75 & 151 & 9.9 & & & & & & \\
\hline 3.00 & 184 & 8.7 & 70 & 10.0 & 34 & 12.5 & 15 & 40.0 \\
\hline 3.25 & & & 41 & 53.0 & & & & \\
\hline 3.50 & 532 & 7.3 & 28 & 7.0 & 31 & 9.7 & 9 & 0 \\
\hline 3.75 & 36 & 8.3 & 23 & 4.3 & & & & \\
\hline 4.00 & 366 & 5.7 & 170 & 2.3 & 73 & 9.6 & 286 & 19.9 \\
\hline 4.25 & 25 & 8.0 & & & & & & \\
\hline 4.50 & 1568 & 9.0 & 338 & 13.3 & 196 & 10.2 & 145 & 21.3 \\
\hline 4.75 & 16 & 12.5 & & & & & & \\
\hline 5.00 & 404 & 6.7 & 23 & 21.7 & & & & \\
\hline 5.50 & 9 & 0 & 126 & 11.9 & 53 & 7.5 & 36 & 7.5 \\
\hline 6.00 & 44 & 6.8 & 90 & 17.7 & 111 & 12.6 & & \\
\hline 6.50 & 57 & 12.3 & & & & & & \\
\hline Total & 3392 & 7.9 & 909 & 15.7 & 498 & 10.35 & 491 & 17.7 \\
\hline
\end{tabular}

Budwoods were gamma irradiated and grafted onto 'Troyer' citrange rootstock $\left(\mathrm{mV}_{1}=\right.$ mutation vegetative 1$)$ and a second grafting $\left(\mathrm{m} \mathrm{V}_{2}=\right.$ mutation vegetative 2) was made onto new 'Troyer' citrange rootstock (see Fig. 1). Screening for seedlessness began 2 years after the first flowering (see Table 4).

grains were counted for each sample. Unstained and partially or poorly stained pollen grains were considered as aborted pollen. The control plants of all four cultivars (Table 4) had wide ranges of seed numbers, up to 30 seeds per fruit. The frequencies of seedless and low-seeded mutants (zero to seven seeds per fruit) in the four cultivars are listed in Table 4. Some of the radiation doses resulted in small numbers of trees, thus the percentage of mutants in these populations can be considered biased.

Another selection criterion was pollen fertility. Pollen fertility was evaluated over two seasons, with rather good consistency across the two seasons. Trees with fruit that had few seeds (zero to seven seeds per fruit) had lower levels of pollen fertility, generally in the range of $2 \%$ to $30 \%$, compared with $80 \%$ to $95 \%$ pollen fertility in the control trees. This positive correlation between pollen fertility and the number of seeds per fruit may reflect the fact that the egg and pollen are both haploid, and therefore more susceptible to the expression of lethal recessive mutations (Hearn, 1986; Vardi et al., 1995, 1996). Our results indicate a common trend in the four cultivars for seedlessness or plants with low seed numbers. Most of the lines selected for further propagation were chosen from material irradiated with the lower dose of radiation, below the $\mathrm{LD}_{50}$. The irradiation approach continues to be an effective method for inducing nearly complete to complete seedlessness in newly selected citrus cultivars (Fig. 2). However, this method is time-consuming and requires a great deal of land.

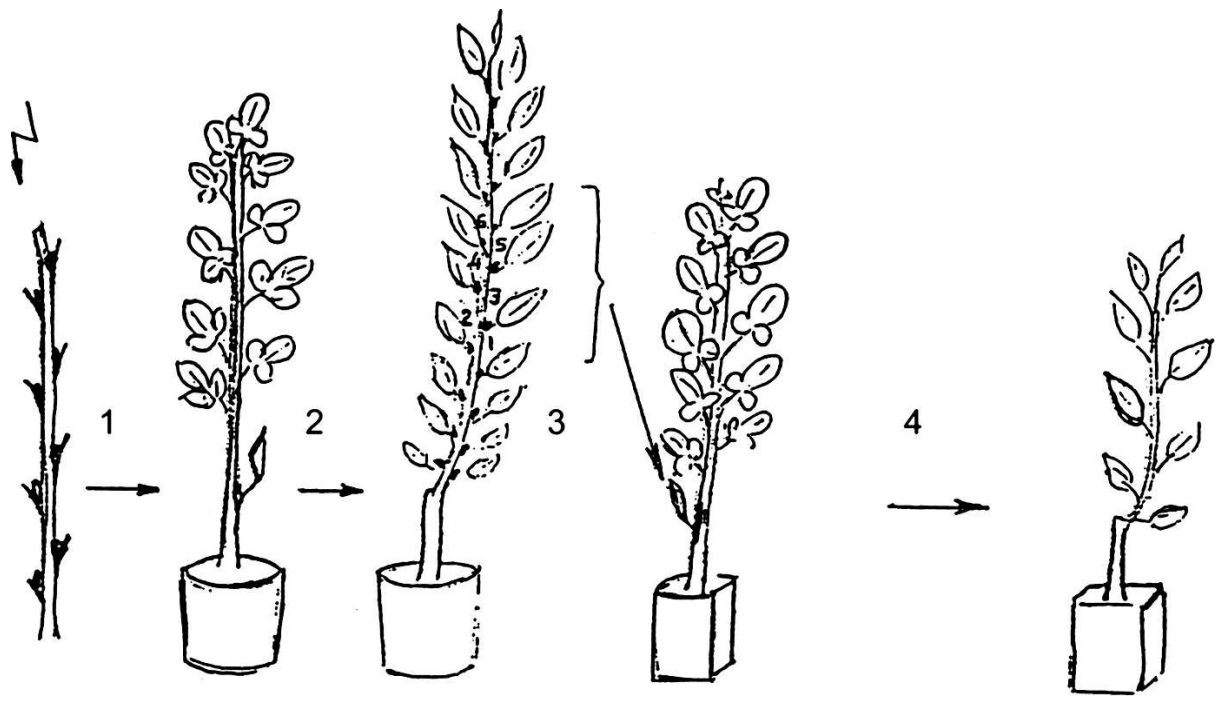

Fig. 1. The sequence of activities for generated mutants. (1) Two-hundred budwoods were gamma irradiated with $13.3 \mathrm{~Gy} / \mathrm{min}{ }^{60} \mathrm{Co}$ (Spiegel-Roy 1990). (2) Individual buds were grafted onto 'Troyer' citrange rootstock and developed into $\mathrm{mV}_{1}$ (mutation vegetative 1) generation plants. (3) Buds that were the 7th to 12 th from the first bud from the bottom were grafted onto individual, new 'Troyer' citrange rootstocks to form $\mathrm{mV}_{2}$ generation plants. (4) These plants were planted and screened for seedlessness.

\section{Biotechnological Methods and Transgenic Approaches}

Parthenocarpy is an important agricultural trait and, therefore, a target for biotechnological research. Auxins and GAs play important roles in parthenocarpic fruit development. Increased levels of these hormones in the ovary or ovule can substitute for pollination and can trigger fruit development, and this has been used for the induction of parthenocarpy in genetic engineering studies. (Carmi et al., 1997, 2003; Ficcadenti et al., 1999; Goetz et al., 2006; Pandolfini et al., 2002; Rotino et al., 1997; Szechtman et al., 1997; Varoquaux et al., 2000). These studies yielded promising results in terms of both quality and quantity of seedless fruit. (Gorguet et al., 2005). Researchers have obtained seedless parthenocarpic fruit by elevating the auxin levels in ovules of transgenic eggplant (Solanum 
Table 4. Time required for initial selection for seedlessness in Citrus.



Budwoods were gamma irradiated with $13.3 \mathrm{~Gy} / \mathrm{min}{ }^{60} \mathrm{Co}$ (Spiegel-Roy, 1990) and grafted onto 'Troyer' citrange rootstock to form $\mathrm{mV} \mathrm{V}_{1}$ (mutation vegetative 1 ) generation. Buds from the $\mathrm{mV}_{1}$ generation were grafted onto new 'Troyer' citrange rootstock to form the $\mathrm{mV} \mathrm{V}_{2}(\mathrm{mutation}$ vegetative 2) generation. Selection for seedlessness begins during the second flowering season of the $\mathrm{mV}_{2}$ generation.

melongena L.), tobacco (Nicotiana tabacum L.), and cucumber plants through the expression of the iaaM gene from Pseudomonas syringae van Hall under the control of the ovule-specific promoter gene DefH9 from Antirrhinum majus L. (Rotino et al., 1997; Yin, 2006). In tomatoes, two different strategies were used for the production of parthenocarpic fruit, both using the TPRP-F1 ovary-specific promoter. The first strategy was based on the overexpression of the $i a H_{\text {gene }}$ of Agrobacterium tumefaciens (Smith \& Towns.) Conn., which encodes an enzyme that catalyzes the production of auxin. These transgenic tomato plants were treated with naphthalene acetamide, which is converted to auxin via hydrolysis by $i a a H$, resulting in elevated auxin levels (Szechtman et al., 1997). In the second method, the auxin sensitivity of the ovaries of transgenic tomato plants was increased through the expression of $\mathrm{rolB}$, an auxin-sensitivity gene from A. rhizogenes (Riker et al.) Conn. (Carmi et al., 1997, 2003).

Genetically modified parthenocarpic tomato plants, carrying the DefH9-RI-iaaM chimeric gene (iaaM, a synthetic agro-
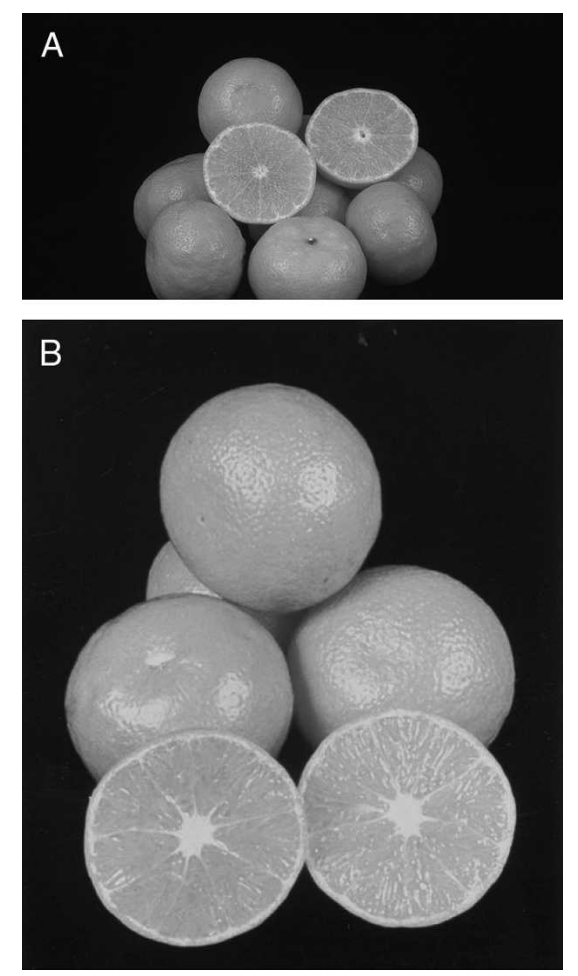

Fig. 2. Seedless mandarin cultivars obtained via budwood irradiation. (A) Orri-seedless Orah. (B) Moria- seedless Murcott. bacterium gene), were grown under open field conditions to allow the comparison of genetically modified fruit with that of the nongenetically modified controls. The genetically modified tomatoes set seedless fruit in open field. There was no yield difference, but fruit numbers were higher and fruit weights were lower in the genetically modified plants (Rotino et al., 2005).

The barnase suicide gene, a cytotoxic ribonuclease of Bacillus amyloliquefaciens Fukumoto, was transformed into tobacco plants, producing transgenic plants with female sterility under the control of a stigma-specific promoter (Goldman et al., 1994) and male sterility under the control of the tapetumspecific promoter pTA29 (Koltunow et al., 1990).

Seedcoat-specific expression of the barnase gene in tomato resulted in the production of seedless fruit (N. Gutersson, pers. comm.). Approaches involving suicide genes, targeting the seedcoat or embryo could result in embryo abortion, and thus stenospermocarpy. Li et al. (2002) reported on a transgenic 'Ponkan' mandarin transformed with the barnase suicide gene under the control of a tapetum-specific promoter (pTA29). These efforts may yield male-sterile mandarins, and therefore seedlessness, in the near future.

\section{Conclusions}

Mutagenesis is not targeted to a specific locus and therefore requires laborious screening of large populations to obtain individual plants exhibiting desired phenotypes. Progress in the Citrus genome project coupled with recent advances in molecular biology techniques should aid the development of faster, targeted, and more efficient tools to expedite citrus breeding.

For instance, DNA markers for traits associated with seedlessness, such as parthenocarpy, male and female sterility, and self-incompatibility, could be used as tools for directed breeding. These markers could be further used in map-based or candidate gene approaches for the cloning of genes that encode important traits, thus expanding the list of genes that can be transformed to induce seedlessness.

Several transgenic approaches for obtaining seedless citrus should be considered. The first approach is male sterility. Many citrus cultivars could potentially set seedless fruit in the absence of pollination. The destruction of pollen through the expression of suicide genes in the tapetum could trigger seedless fruit set in cultivars carrying the parthenocarpic trait. However, this approach is restricted to certain conditions under which transgenic male sterile citrus plants are isolated from male fertile plants. The second approach is seedcoat destruction to obtain stenospermocarpy through the expression of targeted suicide genes during early seedcoat development. In this case, parthenocarpy 
is not required for seedlessness. However, this approach still requires the elimination of cross-pollination, which requires particular growing conditions, such as isolated blocks of selfincompatible cultivars. The third approach is female sterility. Destruction of the ovule or the stigma by suicide genes could trigger seedless fruit set that would not be restricted to isolated blocks, because fertilization would be impossible. However, this approach is limited to cultivars with strong parthenocarpic traits. The fourth and last approach is increased expression or increased sensitivity to GA in the ovary or ovule. This approach, via genetic engineering of auxin expression or sensitivity, has been used successfully in several field crops (Carmi et al., 1997, 2003; Ficcadenti et al., 1999; Goetz et al., 2006; Pandolfini et al., 2002; Rotino et al., 1997; Szechtman et al., 1997; Varoquaux et al., 2000). It will be interesting to apply similar approaches in citrus, such as overexpression of GA 20oxidase or ovary- or ovule-specific GAI silencing. If successful, these approaches could yield obligatorily seedless citrus cultivars. However, tissue-specific, timing-specific, and level-ofexpression promoters should be screened to ensure optimal results and to avoid hormonal side effects.

As outlined in this review, several transgenic approaches for the induction of parthenocarpy in citrus have already been successfully applied, and several others are yet to be explored. However, the commercialization of these products is limited by consumers' reluctance to buy genetically modified foods, particularly in western countries. Therefore, conventional breeding of fruit trees will most likely continue to be a very important way to meet consumer demand for improved fruit quality. Triploidy is probably the most popular method for the development of seedless citrus cultivars. Currently, hundreds of triploid hybrids are produced annually by programs in Spain, the United States, and Israel. Nevertheless, conventional breeding of nongenetically modified cultivars could be significantly expedited through the use of DNA markers. Other emerging biotechnological approaches should also be continuously evaluated for their potential contributions to the acceleration of breeding efforts.

\section{Literature Cited}

Archbold, D.D. and F.G. Dennis. 1985. Strawberry receptacle growth and endogenous IAA content as affected by growth regulator application and achene removal. J. Amer. Soc. Hort. Sci. 110:816-820.

Ben-Cheikh, W., J. Perz-Botella, F.R. Tadeo, M. Talon, and E. PrimoMillo. 1997. Pollination increases gibberellin levels in developing ovaries of seeded varieties of Citrus. Plant Physiol. 114:557-564.

Brock, R.D. 1979. Mutation plant breeding for seed protein improvement, p. 43-55. In: Seed protein improvement in cereals and grain legumes. Intl. Atomic Energy Agency, Vienna.

Broertjes, C. 1977. Artificially induced genetic variation in fruit trees. Acta Hort. 75:19-26.

Broertjes, C. and A.M. Van Harten. 1985. Single cell origin of adventitious shoots. Euphytica 34:93-95.

Broertjes, C. and A.M. Van Harten. 1988. Applied mutation breeding for vegetatively propagated crops. Elsevier, Amsterdam.

Brown, A.G. 1975. Apples, p. 3-38. In: J. Jannick and J.N. Moore (eds.). Advances in fruit breeding. Purdue Univ. Press, West Lafayette, IN.

Bukovac, M.J. and S. Nakagawa. 1967. Comparative potency of gibberellins in inducing parthenocarpic fruit growth in Malus sylvestris Mill. Experientia 23:865 (abstr.).

Bünger-Kibler, S. and F. Bangerth. 1982. Relationship between cell number, cell size and fruit size of seeded fruits of tomato ( Lycopersicon esculentum Mill.), and those induced parthenocarpically by the application of plant growth regulators. Plant Growth Regul. $1: 143-154$.

Cameron, J.W. and H.B. Frost. 1968. Genetics, breeding and nuclear embryony, p. 325-370. In: W. Reuther, L.D. Batchelor, and H.J. Webber (eds.). The Citrus industry. Vol. II. University of California Press, Berkeley.

Campbell, A.I. and C.N.D. Lacey. 1982. Induced mutants of Cox's Orange Pippin apple with increased self-compatibility. Euphytica 31:469-475.

Campbell, A.I. and D. Wilson. 1977. Prospects for the development of disease-resistant temperate fruit plant by mutation induction, p. 215226. In: Proc. Symp. Intl. Atomic Energy Agency, Vienna.

Carmi, N., Y. Salts, B. Dedicova, S. Shabtai, and R. Barg. 2003. Induction of parthenocarpy in tomato via specific expression of the rolB gene in the ovary. Planta 217:726-735.

Carmi, N., Y. Salts, S. Shabati, M. Pilowsky, R. Barg, and B. Dedicova. 1997. Transgenic parthenocarpy due to specific oversensitization of the ovary to auxin. Acta Hort. 447:597-601.

Chao, C.C.T., J. Fang, and P.S. Devanand. 2005. Long distance pollen flow in mandarin orchards determined by AFLP markers: Implications for seedless mandarin production. J. Amer. Soc. Hort. Sci. 130:374-380.

Coggins, C.W., Jr. and H.Z. Hield. 1968. Plant growth regulators, p. 371-389. In: W. Reuther, L.D. Batchelor, and H.J. Webber (eds.). The Citrus industry. Vol. II. University of California Press, Berkeley. Coombe, B.G. 1960. Relationship of growth and development to changes in sugars, auxin and gibberellins in fruit of seeded and seedless varieties of Vitis vinifera. Plant Physiol. 32:241-250.

Coutinho, M.P. 1975. Using radiation to obtain vines resistant to Plasmopara. Vitis 13:281-286.

Dayton, D.F. 1959. Red color distribution in apple skin. J. Amer. Soc. Hort. Sci. 74:72-80.

Dayton, D.F. 1969. Genetic heterogeneity in the histogenic layers of apple. J. Amer. Soc. Hort. Sci. 94:592-595.

de Menezes, C.B., W.R. Maluf, S.M. de Azevedo, M.V. Faria, I.R. Nascimento, D.W. Nogueira, L.A.A. Gomes, and E. Bearzoti. 2005. Inheritance of parthenocarpy in summer squash (Cucurbita pepo L.). Genet. Mol. Res. 4:39-46.

Denna, D.W. 1973. Effects of genetic parthenocarpy and gynoecious flowering habit on fruit production and growth of cucumber Cucumis sativus L. J. Amer. Soc. Hort. Sci. 98:602-604.

Eeuwens, C.J. and W.W. Schwabe. 1975. Seed and pod wall development in Pisum sativum L. in relation to extracted and applied hormones. J. Expt. Bot. 26:1-14.

Esen, A., R.K. Soost, and G. Geraci. 1979. Genetic evidence for the origin of diploid megagametophytes in Citrus. J. Hered. 70:5-8.

Ficcadenti, N., S. Sestili, T. Pandolfini, C. Cirillo, G.L. Rotino, and A. Spena. 1999. Genetic engineering of parthenocarpic fruit development in tomato. Mol. Breed. 5:463-470.

Food and Agriculture Organization of the United Nations, FAO. 2005. 16 Nov. 2007. Available at <http://www.fao.org/waicent/portal/ statistics_fr.asp $>$.

Fos, M., F. Nuez, and J.L. Garcia-Martinez. 2000. The gene pat-2, which induces natural parthenocarpy, alters the gibberellin content in unpollinated tomato ovaries. Plant Physiol. 122:471-480.

Fos, M., K. Proano, F. Nuez, and J.L. Garcia-Martinez. 2001. Role of gibberellins in parthenocarpic fruit development induced by the genetic system pat-3/pat-4 in tomato. Plant Physiol. 111:545550.

Garcia-Martinez, J.L. and M.A. Garcia Papi. 1979. The influence of gibberellic acid, 2,4-dichlorophenoxy-acetic acid and 6-benzylaminopurine on fruit set of 'Clementine' mandarin. Sci. Hort. 10:285293.

Garcia-Martinez, J.L. and P. Hedden. 1997. Gibberellins and fruit development, p. 263-285. In: F.A. Tomas-Barberan and R.J. Robins (eds.). Phytochemistry of fruit and vegetables. Clarendon Press, Oxford, UK. 
Garcia-Martinez, J.L., M. Marti, T. Sabater, A. Maldonado, and Y. Vercher. 1991. Development of fertilized ovules and their role in the growth of the pea pod. Plant Physiol. 83:411-416.

Garcia-Papi, M.A. and J.L. Garcia-Martinez. 1984. Endogenous plant growth substances content in young fruits of seeded 'Clementine' mandarin as related to fruit set and development. HortScience 22:265-274.

George, W.L., J.W. Scott, and W.E. Splittstoesser. 1984. Parthenocarpy in tomato. Hort. Rev. (Amer. Soc. Hort. Sci.) 6:65-84.

Gil, G.F., G.C. Martin, and W.H. Griggs. 1972. Fruit set and development in the pear: Extractable endogenous hormones in parthenocarpic and seeded fruit. J. Amer. Soc. Hort. Sci. 97:731735.

Gillaspy, G., H. Ben-David, and W. Gruissem. 1993. Fruits: A developmental perspective. Plant Cell 5:1439-1451.

Goetz, M., A. Vivian-Smith, S.D. Johnson, and A.M. Koltunow. 2006. AUXIN RESPONSE FACTOR8 is a negative regulator of fruit initiation in Arabidopsis. Plant Cell 18:1873-1886.

Goldman, M.H., R.B. Goldberg, and C. Mariani. 1994. Female sterile tobacco plants are produced by stigma-specific cell ablation. EMBO J. 13:2976-2984.

Gorguet, B., A.W. van Heusden, and P. Lindhout. 2005. Parthenocarpic fruit development in tomato. Plant Biol. 7:131-139.

Grosser, J.W. and F.G. Gmitter, Jr. 1990. Protoplast fusion and Citrus improvement. Plant Breed. Rev. 8:334-379.

Grosser, J.W. and F.G. Gmitter, Jr. 2005. 2004 SIVB proceedings: Thinking outside the cell: Applications of somatic hybridization and cybridization in crop improvement, with Citrus as a model. In Vitro Cell. Dev. Biol. Plant 41:220-225.

Grosser, J.W., F.G. Gmitter, Jr., N. Tusa, G.R. Recupero, and P. Cucinotta. 1996. Further evidence of a cybridization requirement for plant regeneration from Citrus leaf protoplasts following somatic fusion. Plant Cell Rpt. 15:672-676.

Grosser, J.W., P. Ollitrault, and O. Olivares-Fuster. 2000. Somatic hybridization in Citrus: An effective tool to facilitate variety improvement. In Vitro Cell. Dev. Biol. Plant 36:434-449.

Guo, W.W. and X.X. Deng. 2001. Wide somatic hybrids of Citrus with its related genera and their potential in genetic improvement. Euphytica 118:175-183.

Guo, W.W., D. Prasad, Y.J. Cheng, P. Serrano, X.X. Deng, and J.W. Grosser. 2004. Targeted cybridization in Citrus: Transfer of Satsuma cytoplasm to seedy cultivars for potential seedlessness. Plant Cell Rpt. 10:752-758.

Gustafson, F.G. 1936. Inducement of fruit development by growth promoting chemicals. Proc. Natl. Acad. Sci. USA 22:628-636.

Gustafson, F.G. 1942. Parthenocarpy: Natural and artificial. Bot. Rev. 8:599-654.

Hansche, P.E. 1988. Two genes that induce brachytic dwarfing in peach. HortScience 23:604-606.

Hearn, C.J. 1984. Development of seedless orange and grapefruit cultivars through seed irradiation. J. Amer. Soc. Hort. Sci. 109:270 273.

Hearn, C.J. 1986. Development of seedless grapefruit cultivars through budwood irradiation. J. Amer. Soc. Hort. Sci. 111:304-306.

Hensz, R.A. 1971. 'Star Ruby': A new deep red-fleshed grapefruit variety with distinct tree characteristics. J. Rio Grande Valley Hort. Soc. 25:54-58.

Iwamasa, M. 1966. Studies on the sterility in genus Citrus with special reference to seedlessness. Bul. Hort. Res. Sta. Japan Min. Agr. For. Ser. B6:1-77.

Jacobsen, S.E. and N.E. Olszewski. 1993. Mutations at the SPINDLY locus of Arabidopsis alter gibberellin signal transduction. Plant Cell 5:887-896.

Koltunow, A.M., J. Truettner, K.H. Cox, M. Wallroth, and R.B. Goldberg. 1990. Different temporal and spatial gene expression patterns occur during anther development. Plant Cell 2:1201-1224.

Lapins, K.O. 1971. Stella, a self-fruitful sweet cherry. Can. J. Plant Sci. 51:252-253.
Lapins, K.O. 1983. Mutation breeding, p. 74-99. In: J.N. Moore and J. Janick (eds.). Methods in fruit breeding. Purdue Univ. Press, West Lafayette, IN.

Ledbetter, C.A. and D.W. Ramming. 1989. Seedlessness in grapes. Hort. Rev. (Amer. Soc. Hort. Sci.) 11:159-184.

Li, D.D., W. Shi, and X.X. Deng. 2002. Agrobacterium-mediated transformation of embryogenic calluses of Ponkan mandarin and the regeneration of plants containing the chimeric ribonuclease gene. Plant Cell Rpt. 21:153-156.

Lin, S., W.L. George, and W.E. Splittstoesser. 1984. Expression and inheritance of parthenocarpy in 'Severianin' tomato. J. Hered. 75:62-66.

Lukyanenko, A.N. 1991. Parthenocarpy in tomato, p. 167-178. In: G. Kalloo (ed.). Genetic improvement of tomato: Monographs on theoretical and applied genetics 14. Springer-Verlag, Berlin.

Luro, F., F. Maddy, C. Jackquemond, Y. Froelicher, R. Morillon, D. Rist, and P. Ollitrault. 2004. Identification and evaluation of diplogyny in clementine (Citrus clementina) for use in breeding. Acta Hort. 663:841-848.

Mapelli, S., C. Frova, G. Torti, and G.P. Soressi. 1978. Relationship between set, development and activities of growth regulators in tomato fruits. Plant Cell Physiol. 19:1281-1288.

Mau, S.L., J. Raff, and A.E. Clarke. 1982. Isolation and partial characterization of components of Prunus avium L. styles, including an antigenic glycoprotein associated with a self-incompatibility genotype Mazzard cherries. Planta 156:505-516.

Mazzucato, A., A.R. Taddei, and G.P. Soressi. 1998. The parthenocarpic fruit (pat) mutant of tomato (Lycopersicon esculentum Mill.) sets seedless fruits and has aberrant anther and ovule development. Development 125:107-114.

McIntosh, D.L. and K. Lapins. 1966. Differences in susceptibility to apple powdery mildew observed in McIntosh clones after exposure to ionizing radiation. Can. J. Plant Sci. 46:619-623.

Mezzetti, B., L. Landi, T. Pandolfini, and A. Spena. 2004. The defH9iaaM auxin-synthesizing gene increases plant fecundity and fruit production in strawberry and raspberry. BMC Biotechnol. 4:4. 12 July 2007. <http://www.biomedcentral.com/1472-6750/4/4>.

Monselise, S.P. 1986. Citrus, p. 87-108. In: S.P. Monselise (ed.). CRC handbook of fruit set and development. CRC Press, Boca Raton, FL.

Moriguchi, T., T. Motomura, T. Hidaka, T. Akihama, and M. Omura. 1996. Genotype and parental combination influence efficiency of cybrid induction in Citrus by electrofusion. HortScience 31:275278.

Navarro, L., O. Olivares-Fuster, J. Juárez, P. Aleza, J.A. Pina, J.F. Ballester-Olmos, M. Cervera, C. Fagoaga, N. Duran-Vila, and L. Pena. 2004. Applications of biotechnology to Citrus improvement in Spain. Acta Hort. 632:221-234.

Nitsch, J.P. 1952. Plant hormones in the development of fruits. Q. Rev. Biol. 27:33-57.

Nitsch, J. 1970. Hormonal factors in growth and development, p. 427472. In: A.C. Hulme (ed.). The biochemistry of fruits and their products. Vol. II. Academic Press, London.

Nuez, F., J. Costa, and J. Cuartero. 1986. Genetics of the parthenocarpy for tomato varieties 'Sub-Arctic Plenty', '75/59' and 'Severianin'. Z.Pflanzenzüchtung 96:200-206.

Ohgawara, T., S. Kobayashi, E. Ohgawara, H. Uchimiya, and S. Ishii. 1985. Somatic hybrid plants obtained by protoplast fusion between Citrus sinensis and Poncirus trifoliata. Theor. Appl. Genet. 71:1-4. Oiyama, I. and N. Okudai. 1986. Production of colchicine-induced autotetraploid plants through micrograting in monoembryonic Citrus cultivars. Jpn. J. Breeding 36:371-376.

O'Neill, S.D. and J.A. Nadeau. 1997. Post-pollination flower development. Hort. Rev. (Amer. Soc. Hort. Sci.) 19:1-58.

Ozga, J.A., R. van Huizen, and D.M. Reinecke. 2002. Hormone and seed-specific regulation of pea fruit growth. Plant Physiol. 128:1379_ 1389.

Pandolfini, T., G.L. Rotino, S. Camerini, R. Defez, and A. Spena. 2002. Optimisation of transgene action at the post-transcriptional level: 
High quality parthenocarpic fruits in industrial tomatoes. BMC Biotechnol. 2:1. 12 July 2007. <http://www.biomedcentral.com/ 1472-6750/2/1>.

Pharis, R.P. and R.W. King. 1985. Gibberellins and reproductive development in seed plants. Annu. Rev. Plant Physiol. 36:517-568. Philouze, J. and B. Maisonneuve. 1978. Heredity of the natural ability to set parthenocarpic fruits in the Soviet variety 'Severianin'. Tomato Genet. Coop. 28:12-13.

Pike, L.M. and C.R. Peterson. 1969. Inheritance of parthenocarpy in the cucumber (Cucumis sativus L.). Euphytica 18:101-105.

Ponti, O.M.B. and F. Garretsen. 1976. Inheritance of parthenocarpy in pickling cucumbers (Cucumis sativus L.) and linkage with other characters. Euphytica 25:633-642.

Raghavan, V. 2003. Some reflections on double fertilization, from its discovery to the present. New Phytol. 159:565-583.

Rebers, M., T. Kaneta, H. Kawaide, S. Yamaguchi, Y.Y. Yang, R. Imai, H. Sekimoto, and Y. Kamiya. 1999. Regulation of gibberellin biosynthesis genes during flower and early fruit development of tomato. Plant J. 17:241-250.

Robinson, R., D. Cantliffe, and S. Shannon. 1971. Morphactin-induced parthenocarpy in cucumber. Science 171:1251-1252.

Rodrigo, M.J. and J.L. García-Martínez. 1998. Hormonal control of parthenocarpic ovary growth by the apical shoot in pea. Plant Physiol. 116:511-518.

Rotino, G.L., N. Acciarri, E. Sabatini, G. Mennella, R. Lo Scalzo, A. Maestrelli, B. Molesini, T. Pandolfini, J. Scalzo, B. Mezzetti, and A. Spena. 2005. Open field trial of genetically modified parthenocarpic tomato: Seedlessness and fruit quality. BMC Biotechnol. 5:32.

Rotino, G.L., E. Perri, M. Zottini, H. Sommer, and A. Spena. 1997. Genetic engineering of parthenocarpic plants. Nat. Biotechnol. 15:1398-1401.

Saito, W., T. Ohgawara, J. Shimizu, S. Ishii, and S. Kobayashi. 1993. Citrus cybrid regeneration following cell fusion between nuclear cells and mesophyll cells. Plant Sci. 88:195-201.

Sanada, T., T. Nishida, and F. Ikeda. 1988. Resistant mutant to black spot disease of japanese pear 'Nijisseiki' induced by gamma rays. J. Jpn. Soc. Hort. Sci. 57:159-166.

Schwabe, W.W. and J.J. Mills. 1981. Hormones and parthenocarpic fruit set: A literature survey. Hort. Abstr. 51:661-699.

Simmonds, N.W. 1953. Segregations in some diploid bananas. J. Genet. 51:458-469.

Sjut, V. and F. Bangerth. 1981. Effect of pollination or treatment with growth regulators on levels of extractable hormones in tomato ovaries and young fruits. Plant Physiol. 53:76-78.

Soost, R.K. and J.W. Cameron. 1980. 'Oroblanco' a triploid pummelo-grapefruit hybrid. HortScience 15:667-669.

Soost, R.K. and J.W. Cameron. 1985. 'Melogold' a triploid pummelograpefruit hybrid. HortScience 20:1134-1135.

Soressi, G.P. and F. Salamini. 1975. A mono-Mendelian gene inducing parthenocarpic fruits. Rpt. Tomato Genet. Coop. 25:22.

Spiegel-Roy, P. 1990. Economic and agricultural impact of mutation breeding in fruit trees. Mutation Breeding Rev. Vienna 5:215-235.

Spiegel-Roy, P. and A. Vardi. 1981. 'Yafit' and 'Norit': Two new easy peeling mandarin hybrids, p. 57-59. In: Proc. 4th Intl. Citrus Congr. Intl. Soc. Citriculture. Tokyo.

Spiegel-Roy, P. and A. Vardi. 1992. 'Shani,' 'Orah' and 'Winola': Three new selections from our breeding program, p. 72-73. Proc. 7th Intl. Citrus Congr. of the Intl. Soc. Citriculture. Acireale, Italy.

Srinivasan, A. and D.G. Morgan. 1996. Growth and development of the pod wall in spring rape (Brassica napus) as related to the presence of seeds and exogenous phytohormones. J. Agr. Sci. 127:487-500.

Sun, Z., L.M. Lower, and J.E. Staub. 2004. Generation means analysis of parthenocarpic characters in a processing cucumber (Cucumis sativus) population, p. 365-371. In: A. Lebeda and H.S. Paris (eds.). Proc. Cucurbitaceae, 8th Eucarpia Mtg. on Cucurbit Genet. and Breeding, Olomouc, Czech Republic.

Swain, S.M., J.B. Reid, and Y. Kamiya. 1997. Gibberellins are required for embryo growth and seed development in pea. Plant J. 12:1329-1338.
Sykes, S.R. and S. Lewis. 1996. Comparing Imperial mandarin and Silverhill Satsuma mandarins as seed parents in a breeding program aimed at developing new seedless Citrus cultivars for Australia. Austral. J. Expt. Agr. 36:731-738.

Szechtman, A.D., Y. Salts, N. Carmi, S. Shabtai, M. Pilowsky, and R. Barg. 1997. Seedless fruit setting in response to NAM treatment of transgenic tomato expressing the iaaH gene specifically in the ovary. Acta Hort. 447:597-598.

Talon, M., L. Zacarias, and E. Primo-Millo. 1990. Hormonal changes associated with fruit set and development in mandarins differing in their parthenocarpic ability. Plant Physiol. 79:400-406.

Talon, M., L. Zacarias, and E. Primo-Millo. 1992. Gibberellins and parthenocarpic ability in developing ovaries of seedless mandarins. Plant Physiol. 99:1575-1581.

Tobutt, K.R. 1984. Breeding columnar apple varieties at East Malling. Sci. Hort. 35:72-77.

Van Harten, A.M. and C. Broertjes. 1989. Induced mutations in vegetatively propagated crops. Plant Breed. Rev. 6:55-91.

Vardi, A., A. Elhanati, A. Frydman-Shani, and H. Neumann. 1996. Strategies and considerations in mandarin improvement programmes, p. 109-112. In: Proc. 8th Citrus Congr. Intl. Soc. Citriculture. Intl. Soc. Citriculture, Sun City, FL.

Vardi, A., A. Elhanati, A. Frydman-Shani, H. Neumann, and P. Spiegel-Roy. 1995. New considerations on the choice of irradiation dose rate in Citrus, p. 667-670. In: Induce mutation and molecular techniques for crop improvement. International Atomic Energy Agency and Food and Agriculture Organization of the United Nations, Vienna.

Vardi, A., H. Neumann, A. Frydman-Shani, Y. Yaniv, and P. SpiegelRoy. 2000. Tentative model on the inheritance of juvenility, selfincompatibility and parthenocarpy. Acta Hort. 535:199-203.

Vardi, A. and P. Spiegel-Roy. 1981. Gene-controlled meiosis in Citrus reticulata, p. 26-27. In: Proc. 4th Intl. Citrus Congr. Intl. Soc. Citriculture. Tokyo.

Vardi, A. and P. Spiegel-Roy. 1988. A new approach to selection for seedlessness, p. 131-134. In: Proc. 6th Intl. Citrus Congr. Intl. Soc. Citriculture. Tel Aviv, Israel.

Vardy, E., D. Lapushner, A. Genizi, and J. Hewitt. 1989a. Genetics of parthenocarpy in tomato under a low temperature regime I. Euphytica $41: 1-8$.

Vardy, E., D. Lapushner, A. Genizi, and J. Hewitt. 1989b. Genetics of parthenocarpy in tomato under a low temperature regime II. Cultivar 'Severianin'. Euphytica 41:9-15.

Varoquaux, F., R. Blanvillain, M. Delseny, and P. Gallois. 2000. Less is better: New approaches for seedless fruit production. Trends Biotechnol. 18:233-242.

Vivian-Smith, A. and A.M. Koltunow. 1999. Genetic analysis of growth regulator-induced parthenocarpy in arabidopsis. Plant Physiol. 121:437-451.

Yamamoto, M. and S.A. Kobayashi. 1995. Cybrid plant produced by electrofusion between Citrus unshiu (Satsuma mandarin) and C. sinensis (sweet orange). Plant Tissue Cult. Lett. 12:131-137.

Yamamoto, M., S. Kobayashi, T. Yoshioka, and R. Matsumoto. 2001. Cybridization in Citrus unshiu Marc. (Satsuma mandarin) and $C$. sinensis (L.) Osbeck (sweet orange), p. 124-138. In: T. Nagata and Y.P.S. Bajaj (eds.). Somatic hybridization in crop improvement II. Vol. 49. Biotechnology in agriculture and forestry. Springer, Berlin. Yamamoto, M., R. Matsumoto, N. Okudai, and Y. Yamada. 1997. Aborted anthers of Citrus result from gene-cytoplasmic male sterility. Sci. Hort. 70:9-14.

Yamamoto, M., N. Okudai, and R. Matsumoto. 1992. Segregation for aborted anthers in hybrid seedlings using Citrus nobilis $\times$ C. deliciosa cv. Encore as the seed parent. J. Jpn. Hort. Sci. 60:785-789.

Yin, Z., R. Malinowski, A. Ziolkowska, H. Sommer, W. Plcader, and S. Malepszy. 2006. The DefH9-iaaM-containing construct efficiently induces parthenocarpy in cucumber. Cell. Mol. Biol. Lett. 11:279290. 